\title{
The Benefits of Innovation for Small Businesses
}

\author{
Dr. Desire S. Luamba ${ }^{1}$, Dr. Marvin L.J. Blye ${ }^{2}$, Dr. Ir. Edouard M. Mwema ${ }^{3}$, Dr. Irene A. Williams ${ }^{4}$, \\ Dr. Kevin James ${ }^{5}$, and Dr. Joel Chagadama ${ }^{6}$ \\ ${ }^{1}$ Adjunct Faculty of Strategic Finance, Trevecca Nazarene University, Nashville, TN, USA \\ ${ }^{2}$ Chief of Fiscal Services, Department of Transportation-Conduits, City of Baltimore, Maryland, USA \\ ${ }^{3}$ Professor Faculty of Polytechnic, University of Lubumbashi, D.R. of Congo \\ ${ }^{4}$ Senior Contributing Faculty Programs, College of Management and Technology, Walden University, USA \\ ${ }^{5}$ Subcontracts Manager, L3Harris Technologies Inc., Palm Bay, Florida, USA \\ ${ }^{6}$ Chief Executive Officer, Star Light Consulting LLC, Manassas, Virginia, USA
}

*Correspondence: Dr. Desire S. Luamba, luambade@gmail.com

\begin{abstract}
The purpose of this qualitative multiple case study was to explore strategic managerial tools small business owners or managers use to sustain growth over time through Schumpeter's innovation theory. Five small business owners located in North America were interviewed through face-to-face open-ended interview questions. The results from data analysis collected through interview responses indicated that small business owners or managers attested that their businesses were developed when using innovation as a strategic managerial tool. By contrast, small business owners or managers agreed that the lack of using innovation and understanding the reality of the current business context had an adverse impact on business growth. The findings of this study may also provide small business leaders or managers with critical information to ensure success and better understand strategies small businesses need for long-term growth.
\end{abstract}

KEYWORDS: Innovation theory, business growth, small business owners

\section{ARTICLE INFORMATION}

Author(s): Dr. Desire S. Luamba, Dr. Marvin L.J. Blye, Dr. Ir. Edouard M. Mwema, Dr. Irene A. Williams, Dr. Kevin James, and Dr. Joel Chagadama

Received: 22 Sep, 2021; Accepted: 29 Oct, 2021; Published: 10 Nov, 2021; e-ISSN: 2347-4696;

Paper Id: BMN-IJBMR-2021-73;

Citation: doi.org/10.37391/IJBMR.090405

Webpage-link:

https://ijbmr.forexjournal.co.in/archive/volume-9/ijbmr-090405.html

\section{INTRODUCTION}

Promoting small business growth has become a big concern for owners, customers, and governments [1]. Small businesses create jobs and increase government income taxes. However, despite the role of job creation and tax contributors, some researchers analyzed the causes of small business failure and concluded that $50 \%$ of small businesses may collapse within the first stage of their creation for lack of innovative strategies $[2,3,4]$. Integrating the concepts of innovation in business may contribute to providing effective strategies to promote growth. Furthermore, exploring the benefits of innovation theory could lead to improve customer service, sales, and build a strong relationship among business managers, government leaders, and individuals in the local communities.

\section{BACKGROUND}

The theory of innovation has evolved for more than 80 years based on competition and globalization [5]. Per Schumpeter, small business growth affects positively the economic development. Since the 1935 s, innovation has contributed to increased profitability and productivity for many organizations [6]. According to Schumpeter, managers, investors, entrepreneurs who used innovation theory had the chance to develop their business and succeed. Moreover, factors such as technology evolution and globalization have increased business challenges for companies to remain competitive and productive [7]. Many small businesses in the United States failed to succeed for lack of business skills, knowledge, experience, and strategies to effectively compete and sustain growth [8-11]. Bereznoi [12] also argued that business innovation is a critical factor to save investment and ensure high investment returns. Using innovation should be a strategic managerial tool to ensure long-term business growth.

\section{CONCEPTUAL FRAMEWORK}

The theory of innovation was developed by Schumpeter in 1934 to attest that the combination of new ideas, services, or products may result in the creation of products or services which may be beneficial for organizations or communities [6]. Schumpeter [6] also confirmed that introducing new products, changing production methods, expanding markets, finding new resources of production, and developing new structures that align with the organizational goals are the primary concepts of innovation. Schumpeter's innovation theory was the foundation of this research study which helped to understand why some small businesses succeeded and what strategic managerial tools small business owners, leaders, or managers should use to remain competitive and promote growth.

\section{LIMITATIONS}

According to Yin [13], researchers need to determine the limitations of the study because research limitations may affect interpretation, analysis, and findings. The first limitation of the study is that participants may have a different view of the topic and their responses might not reflect the same reality or vision of innovation in small business practices. The second limitation is that some participants may not be willing to 
provide their real strategies or business information regarding their business development or growth.

\section{\% 5. LITERATURE REVIEW ON INNOVATION}

The primary purpose of this research was to explore strategic managerial tools that small business managers used to remain competitive and sustain growth. To reveal these strategies, we analyzed the following themes: (a) impact of innovation on business, (b) business model innovation, (c) causes of business collapsing, and (d) the role of planning in business. The literature review included peer-reviewed journal articles, books, dissertations, and public records collected from government sources, Pro-Quest Central, web pages, and Google Scholar.

\subsection{Impact of Innovation on Business}

In 1934, Schumpeter introduced the theory of innovation and attested that business innovation is one of the primary factors for promoting business development or growth. Business managers and analysts used the theory of innovation to assess organizational growth and business fluctuations [6]. Schumpeter [6] also added that using innovation in business is crucial for promoting the processes of production, transportation, and commercialization which are crucial for business growth [14]. Konstantakis, et al. [15] used an analytic model to analyze the impacts of innovation on the US economy and found that business leaders or managers should promote the development of their organizations by looking beyond invention and too much toward innovation. Innovation leads to the development of new strategies that contribute to reducing production costs and sustaining business longevity [6]. Dhochak and Sharma [16] echoed that innovation leads to a competitive advantage for the long term. In the modern business environment, with the development of technology and the internet, business managers should take advantage of innovation theory to manage their organizations at a low cost and in real-time.

Innovation concepts include business activities that increase profits, such as but not limited to, the acquisition of new technology of production, methods of organizations, and systems of monitoring business processes. The lack of innovation may lead to a financial crisis or business failure [17]. Nevertheless, Suraksha, et al. [18] argued that the development of new products and markets is attainable if companies reach customers' desires. Christensen, et al. [17] echoed that business innovation is crucial for promoting market values and customers retention. Christensen [17] also added that some managers failed not take precautions to analyze customers' needs and prevent the adverse effects of competition, which ultimately threatens business development. Some researchers concluded that adopting innovation in business ensures productivity and growth [19, 20]. Basu et al. [21] argued that the primary goal of business managers is to succeed by promoting productivity, profitability, and sustainability. The impact of globalization on business activities is also an important factor for promoting innovation and growth for businesses [22]. Moreover, globalization increases competition and contributes to improving the quantity and quality of products and services that businesses offer on the market [23]. However, using innovation may result in increased production costs and market challenges. Small business managers or leaders could use innovation as a strategic managerial tool to increase competitiveness and market orientation.

\subsection{Business Model Innovation}

Small businesses need an innovative business model to sustain the growth of their activities. Madonsela, et al. [24] argued that business model innovation is a fundamental change that managers need to align resources, methods, processes, and benefits for the organization's productivity, profitability, and sustainability. Similarly, Philipson [25] claimed that the concepts of the business model innovation are useful to understand the nature of the business and its mission to respond positively to customer demand and increase customer satisfaction or service. The primary purpose of a business model innovation should be to create and increase new resources for the benefit of the organization by improving the value of products or services and meeting customers' demands efficiently [17, 26].

To promote growth, managers should create new ideas and develop new strategies through their business model innovation [6, 17]. Successful business innovation models must align a company's inputs, outputs, and goals [27, 28]. Schumpeter [6] stated that effective business leaders should be able to evaluate growth and prevent the decline in productivity at any time. As business managers play a critical role in identifying new strategies to maximize profits, they should be able to determine their appropriate business model innovation [17]. Business managers who have the ability to develop new ideas and strategies while increasing productivity may significantly promote their business growth.

In the modern business environment, the increasing effect of the competition is another factor that should motivate managers to create or develop new strategies to implement productivity and profitability. For small business managers, it is crucial to increase customers' value and develop price and marketing strategies through business model innovation to remain efficient in the market [29, 30]. Stock, et al. [31] recommended business managers develop sustainable business models that consider environmental, social, and economic factors to ensure organizational growth. Per Stock, et al. [31], managers who experiment and develop a strategic business model have the chance to resolve market challenges and meet companies' goals. As resolving market issues may be challenging, small business managers who understand the role of business model innovation and have appropriate managerial tools to establish a successful pathway to success.

\subsection{Causes of Business Collapsing}

Innovation is critical to prevent business collapsing. Starting a new business could be challenging for entrepreneurs who desire to enter a new market [32]. Schumpeter [6] revealed that promoting innovation may enable entrepreneurs to have 
adequate resources needed to reach their goals and prevent business failure. To Schumpeter, weak managerial, technical, conceptual, and personal skills are among the factors that may weaken the innovation spirit and lead to businesses collapsing [6]. Small business managers encounter many operational business challenges that affect organization growth. Many small companies have collapsed because of a lack of business skills, managerial tools, and business strategies to maintain a high level of production and sales [33, 34]. West and Bogers [35] used the linear process model to analyze the impact of using external sources to the business to improve innovation and prevent business failure. In their conclusion, West and Bogers [35] found that the failure of a company arises from a lack of better identification and analysis of internal and external factors that affect productivity. Per West and Bogers, [35] managers should analyze factors such as the decrease in sales, lack of liquidity, low production and stock turnover, high debts, and customer complaints to prevent business collapsing or failure. Beena and Paul [19] also argued that using innovation as a business strategy may prevent a financial crisis in the organization. Small business managers or leaders should be aware of using innovation as a strategy to manage and analyze all business activities and promote growth.

The causes and symptoms of many small companies' collapsing may arise from many sources. Hsu, et al. [36] analyzed the causes of small companies collapsing and found that the causes of business failure may be internal or external to the organization. $\mathrm{Hu}$ et al., also argued that noncompliance with business regulations and practices are among the causes of business failure. Efficient small business managers need to have managerial and leadership practices to meet organizational goals and prevent collapsing [37]. Gordian and Evers [38] argued that the few ways to prevent failure are increasing business aptitude and compliance with the laws and regulations. Similarly, Walsh and Cunningham [39] also asserted that having appropriate managerial tools helps managers to improve their decision-making and planning capabilities which may prevent failure. Nevertheless, the lack of managerial tools can have obvious damages to a company's innovation efforts.

\subsection{Business Planning}

Innovation is strategic to ensure optimization and efficiency based on planning. Schumpeter [6] stated that innovation increases planning and organization efficiency and contributes to business sustainability. Serven [40] highlighted the role of a realistic project plan or business planning to promote operational activities in businesses. Sihite and Simanjuntak [41] argued that business planning is a necessary indicator of funds management that managers need in investment and working capital to ensure a positive return. Under the theory of innovation, managers who use adequate planning have the chance to succeed [42]. Many business owners close their activities because of the lack of realistic business plans and strategies to sustain competitiveness [2]. Managers must develop a strategic management plan that could prevent financial deficits or any mismanagement to ensure transparency and success.
The funding requirements for managers to increase marketing, promote customers' loyalty, and explore new market opportunities through the innovation process are not often well planned. Foster [43] believed that the lack of an effective planning strategy and a sound budget are among the factors that delay business development. For maintaining shareholders, creditors, and employees' trust; business owners or managers must predict the company's growth [37]. Managers should also identify and prevent potential threats to business activities to ensure survivability. Some authors argued that strategic and efficient plans must include factors such as market trends, industry evolution, and price strategy $[44,45]$. Acquaah and Agyapong [46] warned that during high competition, managers must predict business trends using economic and commercial data. Economic and commercial planning data are crucial elements that small business managers could use to analyze market trends and plan a better future for their organizations.

Planning could be a useful managerial tool for growth if it is well planned over time. Brannan and Wiklund [47] emphasized using business planning to classify and project the future of successful companies. Schumpeter [6] also stated that using innovation leads to an efficient business plan. Moreover, Brannan and Wiklund [47] used the organizational evolutionary theory to classify and examine the relationships between customer information processes, small firm level of experimentation, and business innovation as predictors of firm performance. Brannan and Wiklund [47] found that there is a significant relationship between using innovation and firm performance in the long term. Active managers should have an effective plan to prevent and detect on time any threat that could affect an organization's growth.

\section{QUALITATIVE METHODOLOGY}

This study was based on the qualitative methodology to explore strategic managerial tools that small successful business managers used to implement innovation in their organizations and promote growth. The qualitative method is used by researchers to collect data from different participants with different experiences and perspectives to understand the reasons, opinions, and motivations of the phenomenon analyzed [13]. Qualitative research was more suitable than quantitative or mixed research because this study did not focus on collecting numeric data to test any hypothetical theories. The qualitative approach was also useful to explore effective business tools from real participants who experienced the phenomenon.

The research design of this study was a multiple case study. Patton [48] argued that using a multiple case study design is useful to understand a phenomenon in-depth and answer what, how, and why questions. Phenomenological, narrative, or ethnography designs were not appropriate because this study did not explore human lived experiences, individuals' life stories or a cultural study of participants. The qualitative multiple case study was appropriate to explore in-depth 
innovation theory business managerial tools small business managers or leaders use to sustain growth for a long time.

\section{METHOD}

\subsection{Population and Sampling}

The size of the population for this qualitative multiple case study was aligned with Patton's philosophy. According to Patton [48], the sample size depends on the nature of the study. Patton also argued that a minimum of a sample size of 5 participants is acceptable and depends on the time and resources that researchers may have for the research. 5 small business owners located in the United southeastern region of The United States who have successfully promoted their business growth for more than 5 years were the sample of this study. The United States' southeastern region has millions of small business owners [11]. It was challenging to select all the entire population members because it would be costly and a waste of time. Participants were selected using the purposive sampling method. Yin [13] argued that the purposive sampling method helps to identify and select participants who could provide rich and valuable information to respond to the research question. Using the Google search engine and exploring SBA reports, the purposive sampling method helped select the 5 participants among other successful small business owners located in the United States southeastern region. The purposive sampling also helped to select participants who met the eligibility criteria, which were: (a) be a small business owner or manager for more than 5 years and located in the southeastern region of the United States, (b) have less than 500 employees, and (c) have revenue more than $\$ 50,000,000$ per year.

\subsection{Procedures}

The research question was: What managerial tools do small business owners use to sustain growth for more than 5 years? The six interview questions were: (a) What strategies have you used to maintain your business for more than 5 years? (b) What were the key challenges that you faced when managing your business? (c) How did you resolve the key issues that you encountered when managing your business? (d) What strategies have you used for maintaining customer satisfaction? (e) How have you assessed the effectiveness of your strategies to remain competitive and active in the market? And (f) what else would you like to share about your experience and strategies to sustain your business growth for more than 5 years?

The primary source of data collection was the semi-structured interview questions-responses with successful small business owners or managers who implemented innovation to promote growth. For data collection validity, we referred to Jamshed's research. Patton [48] argued that using open-ended questions allows qualitative researchers to analyze and understand a phenomenon in-depth. Before conducting the interview, we obtained consent from participants to participate freely in this study. We also explained to participants that there were no incentives for being part of this study and they were free to withhold at any time during the research processes. All participants had the same interview questions and the same time of the interview (30 minutes). Interviews were recorded and participants were encouraged to ask questions to avoid misinterpretations and misunderstandings. For data credibility, we used member checking to verify transcripts and ensure data interpretation and transcript reviews were accurate. Researchers use member checking for increasing accuracy, reliability, validity, and credibility of participants' responses $[50,51]$. As required by ethical norms, we used data coding P1, P2, P3, P4, and P5 for participants 1, 2. 3, 4, and 5 to protect participants' privacy and confidentiality.

\section{DATA ANALYSIS}

After collecting data through interview questions, company documents, and public records, we used NVivo 12 software to organize, classify, and analyze data. Data saturation was reached after interviewing the fifth participant. The analysis of codes and themes from NVivo 12 helped to find and understand effective strategic managerial tools small business owners or managers use for sustaining their business growth for more than 5 years. According to Saldana [52], researchers should focus on data quality rather than quantity because the quality positively affects the results of the study. For data quality, we referred to Schumpeter's innovation theory and data collection after using member checking to evaluate business innovation and growth.

Moreover, we used methodological triangulation for the accuracy, validity, and reliability of the study. Methodological triangulation provides a comprehensive view of the phenomenon when collecting data from multiple sources such as interviews, companies' internal documents, and public records $[13,48,52]$. For data analysis, we also followed the 5steps recommended by Yin [13] which include correctly defining problems, designing the research, collecting and interpreting data, and reporting data.

\section{RESULTS}

The results that emerged from NVivo 12 for this study were three major themes (a) adaptation to change, (b) marketing plan, and (c) technology innovation. Nelson [53] and Percy et al. [54] argued that researchers should identify emerging themes from data analysis, codify each theme, and then link the data to the broader analytic context.

Innovation was strategic to advertise on social media, promote customer service and sustain competitivity. Participants also agreed that innovation was crucial to increase survivability and profitability. Four out of five participants attested that innovation technology and the Internet allowed them to organize, plan, monitor, and manage effectively. Taneja et al. [10] added that innovation should be understood as a primary factor that promotes viability and longevity. Participants also confirmed that innovation contributes to maintaining the high quality and quantity of products and services. Participants also agreed that the strategy of selling online and using home deliveries was useful to increase sales and profits.

Three participants P1, P2, and P3 attested that their strategies to use innovative management tools such as QuickBooks 
accounting software contributed to prepare and declare on time their financial statements. Some researchers attested that understanding and complying with business regulations promote business growth and prevent paying penalization fees [38]. Moreover, P1, P2, and P3 added that complying with business regulations ensures a prospective future and prevents the organization from collapsing. P1, P2, and P3 also stated that the acquisition of appropriate technological tools might be costly and efficient to successfully control business activities and prevent fraud because of some negative human behaviors. Beena and Paul [19] also suggested that innovation is crucial for managers to learn and master business regulations for increasing profits and promoting growth.

As stated above, small business managers or owners used innovation to promote business growth and market development. Moreover, innovation helped business owners to remain competitive in the market and secure their business against middle and large companies that have more business experience, strategies, and technical innovation tools. Moreover, understanding the causes of business collapsing was paramount to increase managerial awareness and lead successfully. All participants also indicated that using innovation was strategic to promote managerial skills and create new resources which were crucial for promoting growth.

Moreover, participants suggested that using innovative managerial instruments such as digital marketing to attract customers was significant to increase new resources. Donate and Pablo [9] analyzed the impact of management practices on business growth and found knowledge of business practices impacts long-term business sustainability. Poorkavoos, et al. [55] in their analysis regarding the role of innovation in business concluded that the use of innovation positively increased new business opportunities. Christensen, et al. [17] echoed that innovation in business leads to increasing an organization's resources by promoting products and services qualities. All participants' responses indicated that small business owners used innovation to attract, retain, and satisfy their customers' desires and demands. P2, P3, P4, and P5 confirmed that using innovation as a managerial tool for advertising was efficient to compete and attract new customers. P1, P2, and P3 presented their business plans and described the advantage of acquisition of new scanners for inventory, cameras for control and security, and using automated text messages and emails to interact with customers. After analyzing the interview data and internal documents such as marketing plans, financial statements, and a list of loyal customers, we understood that managers needed innovation to sustain their business's growth. The findings also showed that during the high competition seasons, participants used innovation strategies to increase profits and sales. P1, P2, and P5 warned that technology innovation changed customer and market behaviors. Moreover, participants agreed that innovation helped them to increase profits and promote sustainability. P2 and P3 recommended that business managers should use innovative strategies that align with the company's mission and goals. P2 and P3 also stated that innovation should bring new ideas on how to lead, manage, oversee, and control daily business activities

Moreover, participants confirmed that innovation was crucial to develop changes, marketing plans, and technology innovation tools for many years (see table 1). Similarly, Makhmoor and Rajesh [56] attested in their findings that the use of innovation increased four times profits more than a classic business. P1 stated, "In today's business environment, with the development of innovative technology, managerial information is collected in real-time, and sales predictions are made correctly." P3 echoed, "With innovative technology, the company's production costs decreased significantly." P4 argued, "Innovation strategy helped to advertise through free socio-media such as Facebook, Twitter, and Text message to maintain sales." Four out of five participants suggested that small business leaders should adopt changes, implement marketing plans, and use technological innovation to build an efficient business model based on innovation to increase sales and sustain longevity for the long term. The findings were consistent with the use of innovation as a strategic managerial business tool for business growth and sustainability.

\subsection{Adaptation to Change}

In today's business context, managers need to promote changes in business practices to remain competitive because of the rapid evolution of technology and new business regulations [57, 58]. $\mathrm{Xu}$, et al. [59] indicated that managers need to adopt change because the number of people in the world evolves every day, and this changes business statistics and predictions constantly. P1, P3, and P4 noted that adopting changes in dealing with customers, suppliers, and government leaders positively impacted their business growth (See Table 1). P3 expressed that finding the appropriate business location and hiring local employees enabled the company to increase its customers' number. Moreover, P3 added that changing the strategy to hire new employees locally had a positive impact because a local employee has friends, colleagues, or family members who may be potential customers for the business.

\subsection{Marketing Plan}

Marketing plans are managerial tools that managers use to list all business actions related to advertising and future projects for the short, middle, or long-term [60]. P1, P2, P4, and P5 confirmed using marketing planning as a strategy to promote innovation and target former or new customers. P1, P2, P4, and P5 also noted that their marketing planning which included the use of social media like Facebook, Twitter, WhatsApp, LinkedIn, Newspapers, TV, and instant text messages contributed to advertise and increase customer's desire to buy more and more their products (See Table 1). P2 and P3 also indicated that the strategy of using instant text messages to show new products, wish birthdays to customers, and inform customers of competitors' prices was crucial to retain and attract new customers in the areas.

\subsection{Technology Innovation}

The development of technology affects business activities, customers' attitudes, and productivity [61]. Bercu, et al. [62] 
argued that technology innovation allows managers to have, for example, inventories, sales, production costs and assess business activities in real-time and at a low cost. The results from interviews confirmed that technology innovation is strategic to sustain growth (Table 1). Moreover, the conclusion from the interviews also aligned with Bercu, et al.'s [62] findings which indicated that the use of innovative technology contributed to reduce production costs and increase profits. P2 also noted that using technology innovations like surveillance cameras and barcode scanners enabled the company to reduce losses, increase profits, present a reliable inventory, and sustain growth.

\begin{tabular}{|c|c|c|}
\hline $\begin{array}{c}\text { Nodes/ } \\
\text { Themes }\end{array}$ & $\begin{array}{c}\text { Number of } \\
\text { Participants }\end{array}$ & $\begin{array}{c}\text { \% of Participant } \\
\text { agreement with } \\
\text { themes (Sec) }\end{array}$ \\
\hline Adaptation to change & 4 & 80 \\
\hline Marketing planning & 4 & 80 \\
\hline $\begin{array}{c}\text { Technology } \\
\text { innovation }\end{array}$ & 5 & 100 \\
\hline
\end{tabular}

Table 1: Emerging themes and agreements.

The results of this qualitative multiple case study revealed that (a) adaptation to change, (b) marketing planning, and (c) technology innovation were strategic tools to promote small business growth. Small business managers or owners who use innovation as a strategic managerial tool may have the chance to sustain their business and succeed. Business managers may have different strategies to sustain growth; however, finding appropriate business strategies is crucial to ensure long-term growth. Moreover, all participants indicated that aligning the concepts of innovation with adaptation to change, marketing plan, and technology innovation was strategic for small businesses to remain sustainable, productive, profitable, and therefore, to increase growth for the long term.

\section{DISCUSSION}

The analysis and impact of innovation on small business activities were informative and constructive to understand and explore what business strategies are useful to sustain growth. Moreover, it was challenging to deal with some participants who were also direct managers and owners. Some owners and managers were reluctant to share and provide their managerial planning strategies and skills because of competition. Some of them were reluctant and did not like to share their strategies for competition reasons.

Despite the challenges encountered during the research processes, the information collected and analyzed regarding small business activities could benefit entrepreneurs, small and middle business operators, government agencies, and future researchers. This research's findings will also be beneficial to learn and understand appropriate business managerial tools small business owners need for long-term growth. Moreover, this study's findings would be useful and constructive for other future scholar-researchers, and why not motivate other people to become small business owners or advisors.

\section{CONCLUSION}

Small businesses create jobs and promote social change and economic development. The high rate of small business failure concerns many business owners, managers, entrepreneurs, and government leaders. The impacts of globalization and technological advances on business activities have increased market competition, making it challenging for some small businesses to survive and sustain growth for many years. Small business managers and leaders need to look beyond invention to develop innovative managerial tools and strategies that reduce production costs, increase sales, and sustain longevity. Exploring innovation theory in business practices leads to ensure success and growth. Although, using innovation as a managerial tool contributes to prevent failure and enhance the development of businesses for the long term.

Small business managers or owners should look at their business practices and develop new procedures to ensure appropriate strategies and methods to sustain themselves for the long term. This study's findings revealed a business model innovation focused on (a) adopting changes in organization, (b) developing a comprehensive marketing plan, and (c) relying on technology innovation for sustaining productivity, profitability, and growth. The findings may also contribute to promote a positive social change by increasing the employment rate and enhancing the local economic development from employment taxes and revenues.

\section{REFERENCES}

[1] Dey, P. K., Malesios, C., De, D., Budhwar, P., Chowdhury, S., $\&$ Cheffi, W. (2020). Circular economy to enhance sustainability of small and medium-sized enterprises. Business Strategy and the Environment, 29(6), 2145-2169.

[2] Luamba, D. (2019). Strategies small business owners use to remain sustainable (Doctoral dissertation). Retrieved from ProQuest Dissertations and Theses database. (UMI No. 13806347)

[3] Small Business Administration (SBA). (2016). Advocacy: The voice of small business in government.

[4] U.S. Small Business Administration. (2016a). Frequently Asked Questions.

[5] Buckley, P. J. (2020). The theory and empirics of the structural reshaping of globalization. Journal of International Business Studies, 51(9), 1580-1592.

[6] Schumpeter, J. A. (1935). The analysis of economic change. The Review of Economics and Statistics, 17(4), 2-10.

[7] Parmer, L., \& Dillard, J. (2015). The relationship between personality and consumer behavior buying patterns within the automobile industry. Global Conference on Business \& Finance Proceedings, 10, 286-295.

[8] Bishop, D. (2015). Small firms and the failure of national skills policies: Adopting An institutional perspective. International Journal of Training and Development, 19(1), 69-80.

[9] Donate, M. J., \& de Pablo, J. D. S. (2015). The role of knowledge-oriented leadership in knowledge management practices and innovation. Journal of Business Research, 68, 360370.

[10] Taneja, S., Pryor, M. G., \& Hayek, M. (2016). Leaping innovation barriers to small business longevity. Journal of Business Strategy, 37(3), 44-51.

[11] Office of Small Business Advocate. (OSBA). (2016). Tennessee comptroller of the treasury. 
[12] Bereznoi, B. (2014). Business model innovation in corporate competitive strategy. Problem of Economic Transition, 57(8), 13-33.

[13] Yin, R. K. (2017). Case study research and applications: Design and methods (6th ed.). Thousand Oaks, CA: Sage.

[14] Nightingale, P. (2015). Schumpeter's theological roots? Harnack and the origins of creative destruction. Journal of Evolutionary Economics, 25(1), 69-75.

[15] Konstantakis, K., G. Michaelides, P. and Papageorgiou, T. (2014), "Sector size, technical change and stability in the USA (1957-2006): a Schumpeterian approach", International Journal of Social Economics, 41(10), 956-974.

[16] Dhochak, M., \& Sharma, A. K. (2016). Using interpretive structural modeling in venture capitalists' decision-making process. Decision 43(1), 53-65.

[17] Christensen, C. M., Bartman, T., \& Van Bever, D. (2016). The hard truth about model innovation. MIT Sloan Management Review, 58(1), 31-40.

[18] Suraksha, G., Naresh, M., Michael, C., \& Pantea, F. (2016). Marketing innovation: A consequence of competitiveness. Journal of Business Research, 69, 5671-5681.

[19] Beena S. S., \& Paul, E. (2016). Social innovation model for business performance and innovation. International Journal of Productivity and Performance Management, 65, 256-274.

[20] Virginia, W. (2016). Research methods: Interviews. EvidenceBased Library \& Information Practice, 11(1), 47-49.

[21] Basu, G. S., Dumitrescu, A., Purcarea, A. A., \& Isarescu, W. S. (2016). Defining open innovation concept using business process modeling. Procedia Technology, 22, 1021-1027.

[22] Ralf, P., Joern, N., Mathias, V., Andrea, M., Kevin, O., \& Jens, P. (2015). Service innovation performance and information technology: An empirical analysis from the dynamic capability perspective. International Journal of Innovation Management, 19(4), 1-30.

[23] Ali, A., Warren, D., \& Mathiassen, L. (2017). Cloud-based business services innovation: A risk management model. International Journal of Information, 37, 639-649.

[24] Madonsela, S.N., Mokwakungu, S. C., \& Mbohwa, C. (2017). Continuous innovation as a fundamental enabler for sustainable business practices. Procedia Manufacturing, 8, 278-283.

[25] Philipson, S. (2016). Radical innovation of a business model: Is business modeling a key to understand the essence of doing business? Competitiveness Review, 26, 132- 146.

[26] Santos, F., Pache, A. C., \& Birkholz, C. (2015). Making hybrids work: Aligning business models and organizational design for social enterprises. California Management Review, 57(3), 36-58.

[27] Arnold, V., Benford, T., Canada, J., \& Sutton, S. G. (2015). Leveraging integrated information systems to enhance strategic flexibility and performance: The enabling role of enterprise risk management. International Journal of Accounting Information Systems, 19(1), 1-16.

[28] Taran, Y., Nielsen, C., Montemari, M., Thomsen, P., \& Palouse, F. (2016). Business model configurations: A five-V framework to map out potential innovation routes. European Journal of Innovation Management, 19, 492-527.

[29] Friedel, C. R., Clegome, N. A., Kaufman, E. K., \& Seibel, M. M. (2016). Connecting leadership with preferences toward adaption and innovation. Journal of Leadership Studies, 10(1), 37-39.

[30] Harris, M., \& Patten, K. (2014). Mobile device security considerations for small- and medium-sized enterprise business mobility. Information Management \& Computer Security, 22(1), 97-114.

[31] Stock, T., Obenaus, M., Slaymaker, A., \& Slinger, G. (2017). A model for the development of sustainable innovations for the early phase of the innovation process. Procedia Manufacturing, $8,215-222$.

[32] Mutoko, W. R. (2014). Challenges of access to markets and opportunities for small, medium and micro enterprises (SMMEs) in Botswana. European Scientific Journal, 10(10), 28-38.

[33] Lussier, R. N., \& Halabi, C. E. (2010). A three-country comparison of business success versus failure prediction model. Journal of Small Business Management, 48, 360-377.

[34] Mitchelmore, S., Rowley, J., \& Shiu, E. (2014). Competencies associated with growth of women-led SMEs. Journal of Small Business and Enterprise Development, 21, 588-601.

[35] West, J., \& Bogers, M. (2014). Leveraging external sources of innovation: A review of research on open innovation. Journal of Product Innovation Management, 31, 814-831.

[36] Hsu, D. K., Wiklund, J., \& Cotton, R. D. (2017). Success, failure, and entrepreneurial reentry: An experimental assessment of the veracity of self-efficacity and prospect theory. Entrepreneurship Theory and Practice, 41(1), 19-47.

[37] Blye, M. L. (2020). Reducing the Frequency and Effects of Fraudulent Activities in Community Action Agencies (Doctoral dissertation). Retrieved from ProQuest Dissertation and Theses. (UMI No. 28151060)

[38] Gordian, M., \& Evers, J. (2017). Reducing the risk of noncompliance. Pharmaceutical Executive, 37(2), 30-31.

[39] Walsh, G. S., \& Cunningham, J. A. (2016). Business failure and entrepreneurship: Emergence, evolution and future research. Foundations and Trends in Entrepreneurship, 12, 163-285.

[40] Serven, L. (2017). Is forecasting destroying your planning process? Strategic Finance, 99(1). 34-39.

[41] Sihite, M., \& Simanjuntak, M. A. (2015). The competitive strategy in green building for Indonesian stakeholders. International Journal of Innovation, Management, and Technology, 6(1), 8-15.

[42] Wolf, C., \& Floyd, S. W. (2017). Strategic planning research: Toward a theory-driven agenda. Journal of Management, 43, 1754-1788

[43] Foster, T. A. (2017). Budget planning, budget control, business age, and financial performance in small businesses (Doctoral dissertation). Retrieved from ProQuest Dissertations and Theses database. (UMI No. 10272755)

[44] Brown, R. (2017). The profession: Self-regulation grows, trust and business. Professional Planner, (96), 36-37.

[45] Pironti, M., Cautela, C., \& Christodoulou, J. (2015). Business models' innovation through new customer roles: A designdriven case study. Emerging Issues in Management, (2), 25-41.

[46] Acquaah, M., \& Agyapong, A. (2015). The relationship between competitive strategy and firm performance in micro and small businesses in Ghana: The moderating role of managerial and marketing capabilities. Africa Journal of Management, 1, 172193

[47] Brannan, L. D., \& Wiklund, J. (2016). An analysis of business models: Firm characteristics, innovation, and performance. Academy of Entrepreneurship Journal, 22(1), 1-20.

[48] Patton, M. Q. (2015). Qualitative research and evaluation methods: Integrating theory and practice (4th ed.). Thousand Oaks, CA: Sage.

[49] Birt, L., Scott, S., Cavers, D., Campbell, C., \& Walter, F. (2016). Member checking: A tool to enhance trustworthiness or merely a nod to validation? Qualitative Health Research, 26, 1802-1811.

[50] Varpio, L., Ajjawi, R., Monrouxe, L. V., O'Brien, B. C., \& Rees, C. E. (2017). Shedding the cobra effect: Problematizing thematic emergence, triangulation, saturation, and member checking. Medical Education, 51(1), 40-50.

[51] Saldana, J. (2016). The coding manual for qualitative researchers (3rd ed.). Thousand Oaks, CA: Sage Publications, Inc. 
[52] Morse, J.M. (2015). Critical analysis of strategies for determining rigor in qualitative inquiry. Qualitative Health Research, 25, 1212-1222.

[53] Nelson, J. (2017). Using conceptual depth criteria: Addressing the challenge of reaching saturation in qualitative research. Qualitative Research, 17, 554-570.

[54] Percy, W. H., Kostere, K., \& Kostere, S. (2015). Generic qualitative research in psychology. The Qualitative Report, 20(2), 76-85.

[55] Poorkavoos, M., Duan, Y., Edwards, J. S., \& Ramanathan, R. (2016). Identifying the configurational paths to innovation in SMEs: A fuzzy-set qualitative comparative analysis. Journal of Business Research, 69(12), 5843-5854.

[56] Makhmoor, B., \& Rajesh, V. (2017). Why business model innovation is the new competitive advantage. IUP Journal of Business, 14(1), 7-17.

[57] Garba, A. S. (2017). Promoting entrepreneurship amidst poverty and unemployment: The role of Nigerian educational policies. International Journal of Asian Social Science, 7, 684-695.

[58] Velu, C. (2015). Business model innovation and third-party alliance on the survival of new firms. Technovation, 35(1), 1-11.
[59] Xu, K., Tihanyi, L., \& Hitt, M. A. (2017). Firm resources, governmental power, and privatization. Journal of Management, 43, 998-1024.

[60] Madura, J. (2015). International financial management (12th ed.). Stamford, CT: Cengage Learning.

[61] Isal, Y., Pikarti, G., Hidayanto, A., \& Putra, E. (2016). Analysis of IT infrastructure flexibility impacts on IT-business strategic alignment. Journal of Industrial Engineering and Management, 9, 657-683.

[62] Bercu, A., Tofan, M., \& Cigu, E. (2015). New challenges concerning sustainable local development: Romance case. Procedia Economics and Finance, 20(1), 65-71.

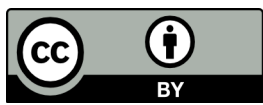

(C) 2021 by the Dr. Desire S. Luamba, Dr. Marvin L.J. Blye, Dr. Ir. Edouard M. Mwema, Dr. Irene A. Williams, Dr. Kevin James, and Dr. Joel Chagadama. Submitted for possible open access publication under the terms and conditions of the Creative Commons Attribution (CC $\mathrm{BY})$

license 